\title{
Floppy Infant
}

National Cancer Institute

\section{Source}

National Cancer Institute. Floppy Infant. NCI Thesaurus. Code C116708.

A syndrome of generalized poor muscle tone and muscle weakness presenting in a newborn infant. 